\title{
The Impact of Sharia Compliance on Sharia Hotel Services and Customers Satisfaction
}

\author{
Hardius USMAN ${ }^{1}$, Nurdin SOBARI ${ }^{2}$, Fahadil Amin AL HASAN ${ }^{3}$ \\ Received: January 16, 2020. Revised: February 04, 2020. Accepted: July 05, 2020
}

\begin{abstract}
Purpose: The main purposes of this study are to examine what the most important hotel facilities that sharia hotels must provide, and to study the relationship between importance of sharia compliance and Muslim tourists' judgment on the performance of sharia hotels. Research Design, Data, and Methodology: The data were collected in Lombok Island. Questionnaires were distributed to Muslim tourists who stayed at one of the sharia hotels, with a total sample of 205 respondents. Factor Analysis Method and Two Independent Sample Tests have been applied in this research to analyze and interpret the data. Result: The results show only one factor is formed from all statements of Sharia compliance variable, and there is a significant difference in the customer experience and customer satisfaction ratings based on the importance of hotel facilities. Conclusion: The present study revealed that Muslim tourists who place a high level of importance in sharia compliance present a more positive assessment for all services provided by sharia hotels. The assessment from Muslim tourists with higher level of importance in Sharia compliance is more positive about their experiences during their stay at the sharia hotels, which also affects their satisfaction.
\end{abstract}

Keywords: Sharia Hotel, Sharia Compliance, Customer Experience, Satisfaction

JEL Classification Code: L83, M31, O53

\section{Introduction}

The halal tourism industry was born due to the special needs of Muslim tourists. As Islam is the way of life, a Muslim is required to perform religious duties everywhere (Begg, 1997), even though they are traveling or on a journey (Jais, 2016). The obligation to live according to Islamic law (sharia) is what causes the special needs of Muslim tourists. The special needs of these Muslim tourists

1 First Author, Professor, Program Studi Statistika Politeknik Statistika STIS Jl. Otista 64 C, Jakarta Timur 13330.

Email: hardius@stis.ac.id

2 Professor, Kajian Timur Tengah dan Islam Universitas Indonesia Gd. IASTH Lt. IV. Kampus UI Salemba, Jakarta Pusat 10430

3. Professor, Kajian Timur Tengah dan Islam Universitas Indonesia Gd. IASTH Lt. IV. Kampus UI Salemba, Jakarta Pusat 10430

(c) Copyright: The Author(s)

This is an Open Access article distributed under the terms of the Creative Commons Attribution Non-Commercial License (https://creativecommons.org/licenses/by-nc/4.0/) which permits unrestricted non-commercial use, distribution, and reproduction in any medium, provided the original work is properly cited. should be satisfied by tour operators (Din, 1989). Therefore it can be stated that halal tourism is a variety of efforts aimed at satisfying Muslim tourists, through the provision of facilities to meet their special needs.

One of the elements of halal tourism that is needed by Muslim tourists is sharia hotels. By definition, a sharia compliance hotel is a hotel that provides services in accordance with the sharia principles (Yusuf, 2009). In conducting its business, sharia hotels provide services that are not different from conventional hotels; yet, sharia hotels are concerned about extended services of conditions and needs of Muslim tourists (Battour, 2015). In other words, sharia hotels are hotels that operate on the basis of sharia values and principles and provide facilities that ease the Muslim tourist in fulfilling their religious obligations.

Nevertheless, satisfying all the special needs of Muslims is not an easy matter because sharia compliance requires the availability of extensive and varied facilities, which bring higher cost consequences. Should the hotel provide a mosque to give Muslim tourists the convenience of praying? 
Should the hotel hold daily religious lectures? Is the hotel able to provide several swimming pools, gyms, or spas, even beaches, especially to separate male and female Muslim tourists?

On the other hand, Muslims have different religious norms (Usman, Tjiptoherijanto, Balqiah, \& Agung, 2017), where one Muslim may believes something is forbidden while another Muslim may not. A group of Muslims may not be able to accept that his/her room is cleaned by an employee whose gender is different from him/her. A group of Muslims may not be able to eat in restaurants that do not separate men and women, or a group of Muslims may also have no conventional bank account. These differences in religious norms make the variety of special needs of Muslim tourists become more diverse. This fact shows the existence of different market segments among Muslims in terms of their special needs.

In examining the vastness and variety of special needs of Muslim tourists, it is necessary to question whether it would be possible for all hotels to meet all of the special needs of Muslim tourists. If it is not possible, how far should hotels go to accommodate the needs of Muslim tourists? Therefore, it is necessary to examine what hotel facilities are considered most important by Muslim tourists to meet their special needs, so that the minimum standard of sharia hotel facilities can be known.

Some previous researches (Haque, Osman, \& Ismail, 2009; Manzoor, Aqeel, \& Sattar, 2010; Sheikh, Taseen, Haider, \& Naeem, 2010; Butt, Saleem, Ahmed, Altaf, \& Jaffer, 2011; Idris, Naziman, \& Januri, 2011; Usman et al., 2017) show that Muslims have different degrees of religiosity. In other words, every Muslim has different obedience in the implementation of sharia. Therefore, it is possible for Muslim tourists to have different views on the importance of the availability of facilities in accordance with sharia by the hotel. A group of Muslims may believe that all sharia compliant facilities are important; while, other groups may consider only some of the most important facilities. Theory of Reason Action (Fishbein \& Ajzen, 1980) states that a person's attitude is determined by his beliefs. Thus, a Muslim who believes that all sharia compliant facilities are very important will tend to have a positive attitude in sharia hotels

Does this positive attitude affect Muslim tourists' judgment on the performance of sharia hotels? To study the relationship, this research uses importance of sharia compliance as indicator of attitude, and customer experience and consumer satisfaction as indicators of Muslim tourists' judgment on the performance of sharia hotels.

Customer experience is the result of interaction between the customer and the product. The experience is personal and implies customer engagement at different levels, whether rational, emotional, sensory, physical, or spiritual (Gentile, Spiller, \& Noci, 2007). Based on experience using products, consumers can provide subjective feedback both directly and indirectly (Meyer \& Schwager, 2007). Customer experience is not influenced by one element/aspect only but is a combination of various aspects (Shaw \& Ivens, 2007). Does the higher positive attitude of a Muslim towards a sharia hotel make them feel they have a better hotel experience?

West Nusa Tenggara Province, especially Lombok Island is one of the provinces prepared by the Indonesian Ministry of Tourism as a halal tourism destination. Progress on the development of halal tourism, at least can be seen from several awards that have been achieved by Lombok tourism, such as: The World's Best Halal Beach Resort, the World's Best Halal Tourism Website, and the World's Best Halal Honeymoon Destinations Those are the reasons why Lombok Island is used as a locus in this research.

\section{Literature Review}

\subsection{Sharia hotels: Concepts and Attributes}

In a simple word, a sharia compliant hotel can be defined as a hotel that provides services in accordance with the sharia principles (Yusuf, 2009). The services provided by sharia hotels are actually no different from conventional hotels, but, as stated by Battour (2015), sharia hotels are concerned about extended services of conditions and the needs of Muslim tourists, that is, to carry out their religious duties.

Din (1982) made an initial effort by proposing several important facilities in Islamic hotels, namely: the availability of prayer rugs, the Quran, prayer beads, and the sign of the Kiblah; the hotel does not provide alcohol; Unmarried couples are not permitted to check in; and hotels may not allow drug trafficking in their buildings. Stephenson, Russel, and Edgar (2010) conducted a study of sharia hotel facilities with a focus on interior design and Islamic financial management. Furthermore, Henderson (2010) proposes Islamic hotel facilities which include: hotel does not provide alcohol, only halal food, Koran and prayer rugs available in every room, bed and toilet position does not face Mecca, bidets in the bathroom, prayer room, entertainment in accordance with Islamic teachings, mostly staff are Muslim, conservative staff dress, separate recreation facilities for men and women, and the availability of the Islamic financial systems.

In Indonesia, the characteristics of sharia hotels are based on Fatwa Dewan Syariah Nasional Majelis Ulama Indonesia (National Sharia Board - Indonesian Council of Ulama) Ref.\#: 108/DSN-MUI/X/2016 on the 
Implementation of Tourism Based on Sharia Principles, namely:

a. Sharia hotels should not provide access facilities on pornography and immoral acts;

b. Sharia hotels should not provide entertainment facilities that lead to idolatry, immorality, pornography, and immoral acts;

c. Food and beverages provided by sharia hotels are required to get a halal certificate from the Indonesian Council of Ulama (MUI);

d. Sharia Hotel should provide adequate infrastructure, equipment, and facilities for worship services;

e. The managers and employees of the hotel shall be obliged to wear appropriate clothing with sharia;

f. Sharia hotels must have a directive and/or guidance on hotel service procedures to ensure the implementation of hotel services in accordance with the principles of sharia;

g. Sharia hotels are required to use the services of Sharia Financial Institutions in performing financial services.

The explanation above shows the special needs of Muslims that must be provided by the hotel quite a lot and very diverse. Is it possible that all hotels are able to meet all these needs? If not, what is the most important thing for a hotel to be called a sharia hotel? Therefore, some researchers (e.g. Weidenfeld, 2005; Okasha, 2010) tried to make a classification of sharia hotels, i.e.: (1) Dry Sharia Hotels, there is no alcohol on the hotel; (2) Partially Sharia Hotels that is providing some basic Muslim needs such as Halal food, prayer rooms, etc; and (3) Fully Syariah Hotels that provide all that is Partially Sharia Hotels, plus regulate hotel management based on Shariah compliance.

Jais (2016) classifies hotels (conventional and sharia) by: (1) Conventional Hotel: The hotel services are not based on the special needs of Muslim tourists, and its management and operation do not need to comply with Sharia requirements; (2) Muslim Friendly Hotel: Hotel fulfills the special needs of Muslims but still provides services that are not in accordance with sharia, such as providing alcohol or nightclubs; (3) Dry Hotel: Services are provided in accordance with sharia, such as not selling alcohol or providing prayer mats and qibla direction in every room. However, Muslim services are still limited; (4) Sharia Compliance: Hotel fulfills the needs of Muslim tourists in accordance with Sharia.

Meanwhile, DinnarStandar (2017) on OIC Muslim Friendly Tourism (MFT) Regulating Accommodation 2017 made the classification of sharia hotels slightly different and more detailed, i.e.: (1) Limited Category: staff training on MFT Principles, some halal food options, list of halal eatries, Qibla direction in room, prayer mat, prayer schedule, list of mosques on request, alcohol-free mini-bar for Muslim guests; (2) Modest Category: prayer mat in room, special ramadhan meal timings, halal food, group mussalla or mosque area, bidet/hand shower in bathrooms, family-friendly entertainment, halal certified kitchen/restaurant, no alcohol, no casinos on site, no nightclubs on site, no adult channel available, and internet content filters in place; (3) Advanced Category: prayer mat in room, special ramadhan meal timings, Islamic artwork, Quran placed in each room, Islamic channels/programming on TV, enviromental certification, staff to wear modest clothes, Islamic finance, living wages, transport to local mosques, group mussalla or mosque area, halal certified wellness product, hotel kitchen to be halal certified, regular congregational/friday prayers, no alcohol, gender-separated wellness facilities (gym, spa, pool, beach), no casinos on site, no nightclubs on site, family-friendly entertainment, boardcast athan on speaker system, no adult channel available, and internet content filters in place.

\subsection{Customer Experience}

Carbone and Haeckel (1994) stated a service always comes with experience. In other words, the experience is the result of a set of interactions between the customer and the service. Customers internally and subjectively have a direct or indirect relationship with the service provider (Meyer \& Schwager, 2007). This experience is personal and implies customer involvement at different levels, whether rational, emotional, sensory, physical, or spiritual (Gentile, Spiller, \& Noci, 2007; Shaw \& Ivens, 2007). This statement is in line with the opinions of Berry and Carbone (2007)-and Voss and Zomerdijk (2007), which state that all service encounters provide an opportunity for emotional engagement.

Customers can feel good or bad experience while interacting with the services provided. Therefore, Lemke, Clark, and Wilson (2010) state that customer experience quality is a perceived assessment of the excellence or superiority of the customer experience. To measure customers assessment of the services provided based on their experience, Lemke et al. (2010) formulated the eight most important aspects that became indicators of customer experience, namely: (1) Accessibility; (2) Competence; (3) Customer Recognition; (4) Helpfulness; (5) Personalization; (6) Problem solving; (7) Promise fulfillment; and (8) Value for Time.

Providing a good experience is important because it will have a positive impact on customer satisfaction (Liljander \& Strandvik, 1997; Venkat, 2007). Mano and Oliver (1993) revealed that experience emotionally brings a positive influence on customer satisfaction. Good customer experience impacts several other aspects, such as customer loyalty (Mascarenhas, Kesavan, \& Bernacchi, 2006; 
Pullman \& Gross, 2004; Yu \& Dean, 2001), increased confidence (Flanagan, Johnston, \& Talbot, 2005), increased brand equity (Grace \& O'Cass, 2004; Berry \& Carbone, 2007) and improve customer relations (Pullman \& Gross, 2004).

\section{Research Hypothesis}

The religiosity that indicates the obedience of a person in performing his religious duties varies between Muslims (Haque et al., 2009; Manzoor et al., 2010; Sheikh et al., 2010; Butt-et al., 2011; Idris et al., 2011; Usman et al., 2017), beside the differences in religious norms among Muslims as revealed by Usman et al (2017). Therefore, it is possible for Muslim tourists to have different views on the importance of the availability of facilities in accordance with sharia by the hotel. A group of Muslims may believe that all sharia compliant facilities are important; while, other groups may consider only some of the most important facilities. Therefore, this study proposes the following hypothesis:

H1: The importance of the attributes of sharia hotels varies among Muslim tourists.

Theory of Reaction Action (Fishbein \& Ajzen, 1980) reveals that a person's attitude will depend on his/her beliefs. On the other hand, Mano and Oliver (1993) revealed that experience emotionally brings a positive influence on customer satisfaction. Muslim tourists who are more obedient to sharia, shown by the higher importance of the attributes of sharia compliance, tend to have a stronger emotional connection with sharia hotels, so they will have a more positive assessment toward the sharia hotels than the less devout Muslim tourists. Therefore, this study also proposes the following hypothesis:

H2: More obedient Muslim tourists perceive a better experience for the services of sharia hotels than the less obedient Muslim tourists.

Customer experience has an impact on customer satisfaction (Mano \& Oliver, 1993; Liljander \& Strandvik, 1997; Venkat, 2007). If the importance of attributes of sharia hotels affects the customer experience, then the importance of attributes of sharia hotel will also affect customer satisfaction. The last hypothesis of this research is:

H3: Muslim tourists who are more obedient will be more satisfied with the services of sharia hotels than Muslim tourists who are less obedient.

\section{Research Method}

The data were collected in Lombok Island, West Nusa Tenggara Province. Questionnaires were distributed to Muslim tourists who stayed at one of the sharia hotels, with a total sample of 205 respondents. For the record, in Lombok actually, there is no hotel that is certified as a sharia hotel. The sharia hotels referred to in this study are more appropriate as hotel friendly to Muslim visitors, numbering 42 hotels. The certificate owned by the hotel is limited to restaurants, not to hotel services. The sampling technique used in this research is purposive sampling, with the following criteria for the respondents:

a. Respondents are 17 years old or above

b. Respondents are Muslims;

c. Stay at one of the Sharia hotels in Lombok.

Table 1: Statement items of Sharia Compliance Variable

\begin{tabular}{|c|c|c|}
\hline Variable & Items Statement & Source \\
\hline \multirow{10}{*}{$\begin{array}{l}\text { Sharia } \\
\text { Compliance }\end{array}$} & $\begin{array}{l}\text { Availability of staff who uses } \\
\text { clothes in accordance with } \\
\text { sharia (Sha1) }\end{array}$ & \multirow{10}{*}{$\begin{array}{c}\text { DinnarStandar } \\
\text { (2017). }\end{array}$} \\
\hline & $\begin{array}{l}\text { Availability of halal food } \\
\text { (Sha2) }\end{array}$ & \\
\hline & $\begin{array}{l}\text { Availability of tools and } \\
\text { equipment for prayer (Sha3) }\end{array}$ & \\
\hline & Availability of mosque (Sha4) & \\
\hline & $\begin{array}{l}\text { Bidet/hand shower in } \\
\text { bathrooms (Sha5) }\end{array}$ & \\
\hline & $\begin{array}{l}\text { Availability of halal-certified } \\
\text { restaurants (Sha6) }\end{array}$ & \\
\hline & No alcohol (Sha7) & \\
\hline & No gambling (Sha8) & \\
\hline & No night club (Sha9) & \\
\hline & $\begin{array}{l}\text { No adult channel available } \\
\text { (Sha10) }\end{array}$ & \\
\hline
\end{tabular}

Note: () is the name of the indicator

As has been explained in the literature review, the attributes of sharia hotels are numerous and varied. In this study, only important attributes are selected, and they should be provided by sharia hotels, so they can be used as a minimum standard for a hotel to be classified as a sharia hotel. This sharia compliance variable is measured by statement items as presented in Table 1, with the measurement scale 6 points semantic differencing $(1=$ very unimportant; $6=$ very important).

To compare the differences of importance level among Muslim tourists to the attributes of sharia hotels, the Sharia 
Compliance Variable was divided into two categories, namely high and low importance. This categorization will also be useful for comparing Muslim tourists' rating of Customer Experience Variable and Customer Satisfaction Variable.

Meanwhile, the dimension to measure the Costumer Experience variable refers to Lemke et al. (2010), which consists of indicators such as helpfulness, value for time, customer recognition, promise fulfillment, problem solving, personalization, competence, and accessibility, with a 6 point measurement scale Likert Scale ( $1=$ strongly disagree; $6=$ strongly agree).

Factor Analysis Method was applied in this research to get the main factor of Variable Sharia Compliance, which is intended to know which attribute is most important for Muslim tourists. Meanwhile, two independent sample test was used to compare assessments of Muslim tourists toward customer experience and satisfaction, between a high and low group of the importance of attributes of sharia compliance.

\section{Result}

The result of Factor Analysis reveals that only one factor is formed from all statements of Sharia Compliance Variable. It can be interpreted that all respondents consider all attributes of sharia compliance, which are proposed in this study, as the most important attributes. Thus, it can be stated that a sharia hotel should at least fulfill the attributes of sharia compliance that are used in this study.

It is possible that these attributes can be supplemented by various attributes that are suggested by academics and practitioners, for example, by beds and toilet positioned so as not to face the direction of Mecca (Henderson, 2010), special Ramadhan meal timings, transport to local mosques, and gender-separated wellness facilities (DinnarStandar, 2017).

If the respondents divided based on the average of Sharia Compliance Variables, there are 135 respondents who rated the importance of the attributes of sharia compliance above average, while the remaining 70 respondents rate this variable below the average. These two groups are then called: the high importance of attributes and the low importance of attributes.

Two Independent Sampling Test results showed that the mean of Variable Sharia Compliance of the two groups differ significantly. This result supports the first research hypothesis (H1) which mentions: The importance of the attributes of sharia hotels varies among Muslim tourists. It indicates that one's adherence to his religion varies, as is the difference in religiosity as in previous researches (such as:
Haque et al., 2009; Manzoor et al., 2010; Sheikh et al., 2010; Butt et al., 2011; Idris et al., 2011; Usman et al., 2017), beside differences in religious norms as mentioned by Usman et al. (2017).

Table 2 shows that No adult channel available, Bidet/hand shower in bathrooms, Availability of tools and equipment for prayer, and No night club, although are important statement items but have lower average values. This condition is thought to be caused by the respondents of this study is an adult group, so 'No adult channel available' and 'No night club' are not the most important attribute to note, or respondents feel able to control it if staying with children. 'Bidet/hand shower in bathrooms' is also not the most important for some Muslims, especially for men who believe that prayers should be held in mosques and carried out in congregation. Muslims also feel that the tools and equipment of prayer are personal needs that every Muslim should have, so the hotel no longer needs to provide.

Table 2: Average of Customer Experience Variable Statement Items

\begin{tabular}{|c|c|}
\hline $\begin{array}{c}\text { Items Statement } \\
\text { Staff use clothes in accordance with sharia } \\
\text { (Sha1) }\end{array}$ & Average \\
\hline Availability of halal food (Sha2) & 5.31 \\
\hline $\begin{array}{c}\text { Availability of tools and equipment for prayer } \\
\text { (Sha3) }\end{array}$ & 5.15 \\
\hline Available mosque (Sha4) & 5.47 \\
\hline Bidet/hand shower in bathrooms (Sha5) & 5.04 \\
\hline The restaurant is halal certified (Sha6) & 5.42 \\
\hline No alcohol (Sha7) & 5.56 \\
\hline No gambling (Sha8) & 5.20 \\
\hline No night club (Sha9) & 5.16 \\
\hline No adult channel available (Sha10) & 4.96 \\
\hline
\end{tabular}

Note: ()is the name of the indicator

The result of the hypothesis test on Consumer Experience Variable based on Muslim group (high vs low the importance of attributes sharia compliance) can be seen in Table 3. The mean of the Helpfulness Variables was higher in the high group than in the low group. This shows that there is a significant average difference between high Importance of Sharia Compliance and low Importance of Sharia Compliance. This result can be interpreted that Muslim tourists who have higher obedience to sharia compliant, also have a higher assessment toward hotel employee services in providing assistance to consumers.

The same result is also shown by the variable value for time, in which the average value of Muslim tourists from the high group is higher than the low group. Hypothesis 
testing also shows that there is a significant mean difference between the two groups. It can be interpreted that Muslim tourists who have stronger adherence to sharia compliant, have a higher rating on hotel employee service in saving consumers time.

Other variables (Customer Recognition, Promise Fulfillment, Problem Solving, Personalization, Competence, and Accessibility of Person / Facility) also show higher rates for Muslim tourists with higher Importance of Sharia Compliance than Muslim tourists with lower Importance of Sharia Compliance. Hypothesis testing also shows that there is a significant mean difference between high and low
Importance of Sharia Compliance on all these variables. It can be interpreted that Muslim tourists who have stricter conviction on the requirements of sharia hotels have higher ratings on the hospitality of hotel staff, hotel fulfillment of promotional promises, hotel services to solve problems, hotel atmosphere and comfort, hotel staff knowledge, and ease of access towards the hotel. These results support the second research hypothesis (H2) which states: More obedient Muslim tourists perceived a better experience for the services of sharia hotels than the less obedient Muslim tourists.

Table 3: Results of Mean Test Two Independent Samples for Variable of Customer Experience and Customer Satisfaction

\begin{tabular}{|c|c|c|c|c|}
\hline Variables & $\begin{array}{l}\text { Category Importance of Sharia } \\
\text { Compliance }\end{array}$ & Mean & t-statistics & p-value \\
\hline \multirow{2}{*}{ Helpfulness } & High & 5.2296 & \multirow{2}{*}{4.645} & \multirow{2}{*}{.000} \\
\hline & Low & 4.8381 & & \\
\hline \multirow{2}{*}{ Value for time } & High & 5.1877 & \multirow{2}{*}{5.495} & \multirow{2}{*}{.000} \\
\hline & Low & 4.7476 & & \\
\hline \multirow{2}{*}{ Customer recognition } & High & 5.1654 & \multirow{2}{*}{4.606} & \multirow{2}{*}{.000} \\
\hline & Low & 4.7000 & & \\
\hline \multirow{2}{*}{ Promise fulfillment } & High & 5.1333 & \multirow{2}{*}{3.916} & \multirow{2}{*}{.000} \\
\hline & Low & 4.7095 & & \\
\hline \multirow{2}{*}{ Problem Solving } & High & 5.2049 & \multirow{2}{*}{5.308} & \multirow{2}{*}{.000} \\
\hline & Low & 4.7238 & & \\
\hline \multirow{2}{*}{ Personalization } & High & 5.2642 & \multirow{2}{*}{5.034} & \multirow{2}{*}{.000} \\
\hline & Low & 4.8714 & & \\
\hline \multirow{2}{*}{ Competence } & High & 5.2278 & \multirow{2}{*}{4.996} & \multirow{2}{*}{.000} \\
\hline & Low & 4.7571 & & \\
\hline \multirow{2}{*}{ Accessibility of person/facility } & High & 5.0840 & \multirow{2}{*}{4.577} & \multirow{2}{*}{.000} \\
\hline & Low & 4.7238 & & \\
\hline \multirow{2}{*}{ Satisfaction } & High & 5.2400 & \multirow{2}{*}{6.440} & \multirow{2}{*}{.000} \\
\hline & Low & 4.5743 & & \\
\hline
\end{tabular}

Based on the results of hypothesis testing above, it was revealed that the assessment of Muslim tourists with high Importance of Sharia Compliance more positive to their experiential along stay at sharia hotel than Muslim tourists with low Importance of Sharia Compliance. In other words, Muslim tourists who have stricter conviction on the terms of sharia hotels more appreciate the various efforts and services provided by sharia hotels. Strong adherence to Sharia compliance, led to the emergence of the attitude that whatever is given by the Sharia hotels is the best, in accordance with the Theory of Reaction Action (Fishbein \& Ajzen, 1980). For the high Importance of Sharia Compliance group, sharia hotels will be the main choice. It means sharia hotels have been superior to conventional hotels without having to compete for services and products provided. This group is a loyalist so it can be stated High Importance of Sharia Compliance group is the main segment of the sharia hotel market.

This condition is in line with the average value of satisfaction variable, in which for Muslim tourists with high Importance of Sharia Compliance is 5.2400, and Muslim tourists with low Importance of Sharia Compliance is 4.5743. The hypothesis testing also shows that there is a significant mean difference between high and low Importance of Sharia Compliance. Thus, it can be stated that the Importance of Sharia Compliance has an influence 
on satisfaction. Muslim tourists who have stricter conviction on the requirements of sharia hotels have higher satisfaction with the efforts and services of sharia hotels. The results of this hypothesis test supports the third research hypothesis (H3), namely: Muslim tourists who are more obedient will be more satisfied with the services of sharia hotels than Muslim tourists who are less obedient, and in line with Mano and Oliver (1993), Liljander and Strandvik (1997), and Venkat (2007), which states Customer experience has an impact on customer satisfaction.

\section{Discussion and Conclusion}

Although Muslims have different beliefs in some contexts, which depend on their religious norms (Usman et al., 2017), generally respondents agree that all items statement about sharia compliance are the main and important needs that must be fulfilled by sharia hotels. Thus it can be stated that those ten items can be used as the standard that must be fulfilled by sharia hotels. Sharia hotels may add some other rules to further satisfy sharia compliance, because it may be that the target market needs it, such as the position of beds and toilets are not facing the direction of Mecca (Henderson, 2010), or gender-separated wellness facilities (StandarDinar, 2017). Conversely, sharia hotels should not loosen the rules by reducing facilities as the items of statement about sharia compliance that is proposed in this study, because it is very likely that a hotel is no longer considered as a sharia hotel by consumers. If that happens, then the hotel will lose the differencing even its superiority from conventional hotels and will compete with it.

Muslim tourists who have high importance of sharia compliance present a more positive assessment of all services provided by sharia hotels. A Muslim who has a higher need for the implementation of sharia compliance at the hotel will feel the need has been met by sharia hotels, which in turn the assessment of various services provided by the sharia hotel will be more positive. Belief raises a positive attitude as the Theory of Reaction Action (Fishbein \& Ajzen, 1980). There is subjectivity when this group of Muslim tourists assessing their experience during using the services of the hotel. Thus, it can be stated that these group of Muslim tourists have a tendency to consider sharia compliance as the main criteria in choosing a hotel than the service or other hotel attributes. Muslim tourist with high of the Importance of Sharia Compliance is supposed to be the main target of sharia hotel marketing because, in this group's view, sharia hotels have excelled to be chosen without competing with conventional hotels.
Meanwhile, Muslim tourists with lower the importance of sharia compliance tend to assess the services provided by the hotel more objectively. This group of Muslim tourists does not directly assess the services provided by the hotel is good just because it is called sharia hotels. So, it is very possible that this group does not make sharia compliance as the main criterion in choosing a hotel, but rather consider the service or other hotel attributes. For this market segment, sharia hotels cannot use solely the sharia compliance as an advantage but must demonstrate the excellence of service and superiority of other attributes. It is possible the hotel in this context should compete with conventional hotels.

The assessment of Muslim tourist with higher level of importance in Sharia Compliance is more positive to their experience during their stay at the sharia hotels, which also affects their satisfaction. Refer to Mano and Oliver (1993), Liljander and Strandvik (1997), Venkat (2007) which stated that customer experience has an impact on customer satisfaction, then based on the result of this study, it can be stated that the Importance of Sharia Compliance, directly and indirectly, has impact on satisfaction. The group with high Importance of Sharia Compliance experiences higher satisfaction than the group with low Importance of Sharia Compliance, due to the subjectivity of assessment resulting from beliefs and attitudes towards sharia hotels

\section{References}

Battour, M. (2015). Halal tourism: Concepts, practices, chall enges and future. Review Elsevier. https://doi.org/http://dx. doi.org/10.1016/j.tmp.2015.12.008.

Begg, M. (1997). Islam and traveling. Retrieved July 13, 2011, from http://www.islamiccentre.org

Berry, L. L., \& Carbone, L. P. (2007). Build loyalty through experience management. Quality Progress, 40(9), 26-32.

Butt, I., Saleem, N., Ahmed, H., Altaf, M., \& Jaffer, K. (2011). Barriers to adoption of Islamic banking in Pakistan. Journal of Islamic Marketing, 2(3), 259-273.

Carbone, L. P., \& Haeckel, S. H. (1994). Engineering Customer Experiences. Journal of Marketing Management, 3 (3), 8-19.

Din, H. K. (1982). Tourism in Malaysia: Competing Needs in the Plural Society. Annuals of Tourism Research, 9, 453-480.

DinarStandard (2017). Muslim Friendly Tourism: Regulating Accommodation Establishments in the OIC Member Count ries. Retrieved May 22, 22019, from http://www.comcec.org/en/wp-content/uploads/2017/02/9TUR-PRE-3.pdf

Fatwa Dewan Syariah Nasioanal MUI (2016). Pedoman Penyelenggaraan Pariwisata Berdasarkan Prinsip Syariah.

Fishbein, M., \& Ajzen, I. (1980). Belief, Attitude, Intention and Behavior: An Introduction to Theory and Research. Reading, MA: Addison-Wesley.

Flanagan, P., Johnston, R., \& Talbot, D. (2005). "Customer 
confidence: the development of a "pre-experience" concept." International Journal of Service Industry Management, 16(4), 373-384.

Gentile, C., Spiller, N., \& Noci, G. (2007). How to Sustain the Customer Experience: An Overview of Experience Components that Co-create Value with the Customer. European Management Journal, 25 (5), 395-410.

Grace, D., \& O'Cass, A. (2004). "Examining service experiences and post-consumption evaluations." Journal of Services Marketing, 18(6), 450-461.

Haque, A., Osman, J., \& Ismail, A. Z. (2009). Factor Influences Selection of Islamic Banking: A Study on Malaysian Customer Preferences. American Journal of Applied Sciences, 6(5), 922928.

Henderson, J. C. (2010). Sharia-Compliant Hotels. Tourism and Hospitality Research, 10(3), 246-254.

Idris, A. R., Naziman,N. M., \& Januri, S. S. (2011). Religious Value as the Main Influencing Factor to Customers Patronizing Islamic Bank. World Applied Sciences Journal 12 (Special Issue on Bolstering Economic Sustainability, 2011).

Jais, A. S. (2016). Sharia Compiance Hotel: Concept and Design (1st ed.). Melaka, Malaysia: Politeknik Merlimau Melaka.

Johnson, C., \& Mathews, B. P. (1997). "The influence of experience on service expectations." International Journal of Service Industry Management, 8(4), 290-305.

Lemke, F., Clark, M., \& Wilson, H. (2010). Customer Exper ience Quality: An exploration in business and consumer c ontexts using repertory grid. Journal of the Academy of Marketing Science, 39(6), 846-869. DOI 10.1007/s11747010- 0219-0

Liljander, V., \& Strandvik, T. (1997). Emotions in service satisfaction. International Journal of Service Industry Management, 8(2), 148-69.

Mano, H., \& Oliver, R. L. (1993). Assessing the Dimensionality and Structure of the Consumption Experience: Evaluation, Feeling, and Satisfaction. Journal of Consumer Research, 20(3), 451-466.

Manzoor, M. M., Aqeel, M., \& Sattar, A. (2010). Factors Paving the Way towards Islamic Banking in Pakistan. World Academy of Science, Engineering and Technology, 66. 1677-1683.

Mascarenhas, O. A., Kesavan, R., \& Bernacchi, M. (2006).
Lasting customer loyalty: a total customer experience approach. Journal of Consumer Marketing, 23(7), 387-405.

Meyer, C., \& Schwager, A. (2007). Understanding customer experience. Harvard Business Review, 85(2), 116-126.

Okasha, Q. (2010). Sharia compliance hotel a framework for destination selection applied on Kuwait and UK (Master's thesis). Maastricht school of management, Maastricht, Netherlands.

Pullman, M. E., \& Gross, M. A. (2004). Ability of Experience Design Elements to Elicit Emotions and Loyalty Behaviors. Decision Science, 35(3), 551-578.

Shaw, C., \& Ivens, J. (2007). Building Great Customer Experience (1st ed.). New York, NY: Pelgrave mac Millan.

Sheikh, M. A., Taseen, U., Haider, S. A., \& Naeem, M. (2010). Islamic Vs Conventional Banks in Pakistan (A case study of Bahawalpur).

Stephenson, M. L., Russel, K. A., \& Edgar, D. (2010). Islamic Hospitality in the UAE: Indigenization of Products and Human Capital. Journal of Islamic Marketing, 1(1), 9-24.

Usman, H., Tjiptoherijanto, P., Balqiah, T. E., \& Agung, I. G. N. (2017). The Role of Religious Norms, Trust, Importance of Attributes, and Information Sources in the Relationship Between Religiosity and Selection of the Islamic Bank. Journal of Islamic Marketing, 8(2). doi: 10.1108/JIMA-012015-0004.

Venkat, R. (2008). Impact of Customer Experience on Satisfaction, Brand Image and Loyalty: A Study in a Business to Business Context. Journal of Marketing, Sobey School of Business, 22, 101-114.

Voss, C., \& Zomerdijk, L. (2007). Innovation in Experiential Services - An Empirical View (pp.97-134). London, United Kingdom: DTI.

Weidenfeld, A. (2005). Religious needs in the hospitality industry. Tourism and Hospitality Research, 6(2), 143-159.

Yu, Y. T., \& Dean, A. (2001). The contribution of emotional satisfaction to customer loyalty. International Journal of Service Industry Management, 12(3), 234-251.

Yusuf, S. (2009). The Real Sense of Sharia Hospitality Concept. Paper Presented at The World Halal Forum, Kuala Lumpur, Malaysia. 